\title{
Inducers and autoinducers on Salmonella enterica serovar Typhimurium motility, growth and gene expression
}

\author{
Indutores e autoindutores na motilidade, no crescimento e \\ na expressão gênica de Salmonella enterica serovar Typhimurium
}

\author{
Rita de Cássia dos Santos da Conceição ${ }^{I^{*}}$ Régis Tuchtenhagen Sturbelle \\ Cláudio Dias Timm ${ }^{\mathrm{I}}$ Fábio Pereira Leivas Leite ${ }^{\mathrm{I}}$
}

\section{ABSTRACT}

Genus Salmonella bacteria are among the major pathogenic microorganisms in food. This bacterium pathogenicity is related to a number of virulence factors, among which its flagella. Flagellum expression is one of the virulence factors modulated by Quorum Sensing. Epinephrine produced by mammals uses the same signaling pathway of the 3 bacteria autoinducer. This study evaluated the effect of molecules inducer (epinephrine) and autoinducers (autoinducer 2 and autoinducer 3) and their association with the motility, growth and expression genes $f h C$, fiA, fii, motA, motB e fliC of Salmonella Typhimurium (ST). Initially, ST was inoculated in BHI. Then, motility assays, growth curves and gene expression were performed by testing different concentrations of epinephrine $(50,125,250,500 \mu \mathrm{M})$, conditioned medium (10 and 50\%) and a combination of these. ST was exposed to different concentrations of epinephrine, conditioned medium and an association of both. Following, motility assays, bacterial growth and gene expression were performed. The results obtained showed that the combination of $500 u M$ epinephrine with $50 \%$ conditioned medium increased ST bacterial motility by increasing the expression of genes involved in flagellum assembly.

Key words: Quorum sensing, Salmonella, epinephrine, autoinducer, motility.

\section{RESUMO}

Salmonella está entre os principais micro-organismos patogênicos veiculados por alimentos. A patogenicidade dessa bactéria está relacionada a uma série de fatores de virulência e, dentre estes, podemos citar os flagelos. A expressão do flagelo está entre os fatores de virulência modulados por Quorum Sensing. $A$ adrenalina produzida pelos mamíferos utiliza a mesma via de sinalização do autoindutor 3 das bactérias. Nesse sentido, este trabalho teve como objetivo avaliar o efeito de moléculas indutora (adrenalina) e autoindutoras (auto-indutor 2 e auto-indutor 3) $e$ a associação destas na motilidade, no crescimento celular e na expressão dos genes fhC, fliA, fliY, motA, motB efliC de Salmonella
Typhimurium (ST). Inicialmente, ST foi semeada em caldo BHI. Após, ensaios de motilidade, curvas de crescimento e expressão gênica foram feitos, testando diferentes concentrações de adrenalina $(50,125,250,500 \mu \mathrm{M})$, meio condicionado $(10$ e $50 \%$ e a associação destes. A partir dos resultados obtidos, observou-se que o tratamento que utilizou $50 \%$ de meio condicionado $+500 \mu \mathrm{M}$ de adrenalina aumentou a motilidade de ST, em decorrência do aumento de genes envolvidos com montagem do flagelo.

Palavras-chave: Quorum sensing, Salmonella, adrenalina, autoindutores e motilidade.

\section{INTRODUCTION}

Genus Salmonella spp. bacteria are among the major pathogenic microorganisms transmitted by food in the world (CDC, 2011), and animal-derived products are the main carriers of this bacterium (BOSILEVAC et al., 2009; MURMANN et al., 2009). Salmonella Enteritidis and Salmonella Typhimurium are the main serovars isolated from human sources (CDC, 2011).

The pathogenicity of this bacterium is related to a number of virulence factors, among which its flagella (METCALFE et al., 2010). The flagellum is an important structure for bacterial motility and its expression is one of the pathogenicity factors modulated by Quorum Sensing (BEARSON \& BEARSON, 2008; WALTER \& SPERANDIO, 2006).

The term Quorum Sensing is used to designate a signaling system between bacteria which

IFaculdade de Veterinária, Universidade Federal de Pelotas (UFPel), 96010-900, Pelotas, RS, Brasil. E-mail: ritinhaconceicao@hotmail.com. ${ }^{*}$ Corresponding author. 
produce substances called autoinducers (AI). The bacteria produce, release, detect and respond to these molecules and when these self-inducers reach a specific concentration, there is the activation of transcription factors which regulate gene expression (SPERANDIO et al., 2003).

So far three types of autoinducers have been described in Gram-negative bacteria. AI-1 is primarily involved in intracellular communication and AI-2, in communication between species, a third autoinducer - AI-3 - is also responsible for activating gene expression in Salmonella (SPERANDIO et al., 2003; BEARSON \& BEARSON, 2008).

Epinephrine and norepinephrine are catecholamines produced by mammals which make use of the same signaling route as AI-3 (SPERANDIO et al., 2003). These neurotransmitters released by sympathetic nervous system work as molecules that can activate/repress microorganism gene expression (O'DONNELL et al., 2006; MOREIRA et al., 2010).

Studies have shown the in vitro activity of these catecholamines in various processes, such as motility (BEARSON \& BEARSON, 2008; SPERANDIO et al, 2003), bacterial cell growth (FREESTONE et al., 2007) as well as in vivo activity (STURBELLE et al., 2013), thus suggesting a communication between pathogen and host. This study aimed to make an in vitro evaluation of the effect of inducing (epinephrine) and self-inducing (autoinducer 2 and autoinducer 3) molecules on the motility, cell growth and expression of Salmonella Typhimurium (ST) flhC, fliA, fliY, motA, motB and fliC genes.

\section{MATERIAL AND METHODS}

\section{Bacteria and culture media}

A Salmonella enterica serovar Typhimurium (ST) strain provided by the Animal Product Laboratory (LIPOA-UFPel-Pelotas-RS) was used in this study (TIMM et al., 2007). Brain-heart infusion broth (BHI, Acumedia, Michigan, USA) and Brain-Heart Infusion agar (BHA, Acumedia, Michigan, USA) were used as culture media. Epinephrine $\left(\mathrm{C}_{9} \mathrm{H}_{13} \mathrm{NO}_{3}\right.$, E1635, Sigma, USA) was used at $50,125,250$ and $500 \mu \mathrm{M}$ concentrations.

\section{Conditioned medium preparation}

Conditioned medium refers to the use of a Salmonella Typhimurium supernatant culture filtered and added to culture media. Salmonella Typhimurium was grown in BHI broth (Acumedia, Michigan, USA) and incubated at $37^{\circ} \mathrm{C}$ for $18 \mathrm{~h}$.
Optical density of each culture was measured by a spectrophotometer (SP-Biospectro 22) and adjusted to $1.0(\mathrm{~A} 600 \mathrm{~nm})$; aliquots were plated in $100 \mathrm{~mL} \mathrm{BHI}$ broth (Acumedia, Michigan, USA) and incubated in an orbital shaker (CertomatR BS-T) at $37^{\circ} \mathrm{C}$ at $130 \mathrm{rpm}$ for $7 \mathrm{~h}$. Afterwards, the BHI broth culture (Acumedia, Michigan, USA) was centrifuged twice at $13,000 \mathrm{~g}$ for 20 minutes, and the supernatant was filtered $(0.22 \mu \mathrm{m}$ filter, Millipore, Brazil).

Motility assays

Motility assay was performed as suggested by SPERANDIO et al. (2002) with modifications. These changes were related to culture medium, treatment and incubation period. Salmonella Typhimurium was grown in BHI broth (Acumedia, Michigan, USA) and incubated at $37^{\circ} \mathrm{C}$ at $130 \mathrm{rpm}$ for 7 hours in an orbital shaker (CertomatR BS-T) and $1 \mu \mathrm{L}$ of the culture was then inoculated in each petri dish containing BHI broth (Acumedia, Michigan, USA) solidified with $0.3 \%$ agar. Epinephrine and conditioned medium were added to the culture medium in adequate proportion for each treatment analyzed after being sterilized and having their temperature decreased. After the addition of epinephrine and conditioned medium, the media were distributed into previously identified Petri dishes and seeded with 1uL Salmonella inoculum after agar solidification. The following treatments were performed: BHI (control), $\mathrm{BHI}+50 \mu \mathrm{M}$ epinephrine, $\mathrm{BHI}+125 \mu \mathrm{M}$ epinephrine, $\mathrm{BHI}+250 \mu \mathrm{M}$ epinephrine, $\mathrm{BHI}+500 \mu \mathrm{M}$ epinephrine, $\mathrm{BHI}+10 \%$ conditioned medium $(\mathrm{cm}), \quad \mathrm{BHI}+10 \% \mathrm{~cm}+50 \mu \mathrm{M}$ epinephrine, $\quad \mathrm{BHI}+10 \% \mathrm{~cm}+125 \mu \mathrm{M}$ epinephrine, $\mathrm{BHI}+10 \% \mathrm{~cm}+250 \mu \mathrm{M}$ epinephrine, $\mathrm{BHI}+10 \% \mathrm{~cm}+500 \mu \mathrm{M}$ epinephrine, $\mathrm{BHI}+50 \% \mathrm{~cm}, \quad \mathrm{BHI}+50 \% \mathrm{~cm}+50 \mu \mathrm{M}$ epinephrine, $\mathrm{BHI}+50 \% \mathrm{~cm}+125 \mu \mathrm{M}$ epinephrine, $\mathrm{BHI}+50 \% \mathrm{~cm}+250 \mu \mathrm{M}$ epinephrine, and $\mathrm{BHI}+50 \% \mathrm{~cm}+500 \mu \mathrm{M}$ epinephrine. The plates were incubated at $37^{\circ} \mathrm{C}$ for 12 hours and motility halos were measured in centimeters with a caliper.

\section{Cell growth}

In order to evaluate the influence of the treatments used in cell growth, Salmonella Typhimurium was initially grown in BHI broth (Acumedia, Michigan, USA) to obtain pre-inoculum, optical density of each culture was measured by a spectrophotometer (SP Biospectro-22) and the inoculum adjusted to $\mathrm{OD}=1.0$ (A600); $2 \mathrm{ml}$ inoculum was then added to each $100 \mathrm{~mL}$ BHI broth (Acumedia, Michigan, USA), corresponding to a 
count of $\sim 1 \times 10^{9} \mathrm{CFU} \mathrm{mL} \mathrm{m}^{-1}$. A standard inoculum plate count to check the amount of inoculated bacteria was performed. Then, treatments were incubated in an orbital shaker (CertomatR BS-T) at $37^{\circ} \mathrm{C}$ for at $130 \mathrm{rpm}$ for $7 \mathrm{~h}$; every hour, an aliquot of each treatment was extracted and quantified by optical density in a spectrophotometer (Biospectro SP-22).

\section{qRT-PCR}

Salmonella Typhimurium was grown in BHI broth (Acumedia, Michigan, USA) at $37^{\circ} \mathrm{C}$ at 130rpm for 7 hours in an orbital shaker (CertomatR BS-T). Afterwards, the culture was centrifuged at $13,000 \mathrm{~g}$ for 20 minutes and the pellet was used to inoculate the control (BHI broth) and selected treatment $(50 \%$ conditioned medium $+500 \mu \mathrm{M}$ epinephrine). Every thirty minutes of incubation at $37^{\circ} \mathrm{C}$, samples were collected, centrifuged and the pellet was suspended in Trizol (Invitrogen, USA). Four samples of each treatment were performed and total RNA was extracted and quantified in a spectrophotometer (NanoVue), and standardized at 1000ng for each cDNA synthesis reaction. Synthesis of cDNA was p4erformed using the High Capacity cDNA Reverse Transcription Kit (Applied Biosystems AB) according to manufacturer instructions; the cDNA obtained was quantified in a spectrophotometer (NanoVue) and stored at $-20^{\circ} \mathrm{C}$ for further use. The expression of flagellum-related genes was determined by real time polymerase chain reaction (RT-PCR). The primers used (Sigma Aldrich, Brazil) were designed by the Primer 3 v. 0.4.0 software under GenBank access number HM583969 for $16 \mathrm{~S}$ ribosomal RNA, motB (NP 460879) and fliC (NP_460912) genes. The following primer sequence was used in the experiment: 16S: forward: AGGCCTTCGGGTTGTAAAGT and reverse: GTTAGCCGGTGCTTCTTCTG; motB: forward: ATGAAAAATCAGGCTCATCCCA and reverse: CATAAAATCGGCGTAGGCAATT; fliC: forward: GGCACAAGTCATTAATACAAACAGC and reverse: TCTTTCGCGCTGTTGATACG. motA (FINK et al., 2007) and fliA (BEARSON \& BEARSON, 2008) primer sequences used in the study followed the cited references.

Reactions were performed in duplicate on an Applied Biosystems ${ }^{\circledR} 7300$ Real-Time PCR System using a Platinum SYBR Green qPCR SuperMix UDG kit (Applied Biosystems) according to manufacturer instructions. Real-time PCR reaction consisted of 236ng cDNA, $6.25 \mu \mathrm{L}$ Platinum ${ }^{\circledR} \mathrm{SYBR}^{\circledR}$ Green, $0.25 \mu \mathrm{L}$ Rox Reference Dye, $0.5 \mu \mathrm{L}$ of each primer and water up to a $12.5 \mu \mathrm{L}$ volume. Samples underwent 45 cycles under the following thermocycling conditions: $95^{\circ} \mathrm{C}$ for 30 seconds, $55^{\circ} \mathrm{C}$ for 30 seconds and $72^{\circ} \mathrm{C}$ for 60 seconds. Resulting data analysis was performed using Real-Time MxPro-Mx3005P software. The relative amount of mRNA for each gene was determined by the comparative threshold cycle $\left(\Delta \Delta \mathrm{C}_{\mathrm{T}}\right)$ method, which was standardized using the $16 \mathrm{~S}$ RNA gene sequence.

\section{Statistical analysis}

The motility halo and growth dynamics were analyzed by $\mathrm{T}$ test using the 2009 version Statistics software $\left(\mathrm{SAS}^{\circledR}, 2009\right)$, and $\mathrm{P}<0.05$ was considered significant. Each assay was performed in triplicate, and the results were expressed as the mean of three independent experiments.

\section{RESULTS AND DISCUSSION}

For bacterial motility, the results obtained demonstrated that $250 \mu \mathrm{M}$ epinephrine, $50 \%$ conditioned medium and 50\% conditioned media + $500 \mu \mathrm{M}$ epinephrine treatments showed larger halo motility, reaching $4.9,6.1$ and $6.2 \mathrm{~cm}$ in diameter, respectively, thus representing a more than two fold increase when compared to control $(2.8 \mathrm{~cm})$ (Figure 1A-C). The other analyzed epinephrine concentrations did not present any statistical differences $(\mathrm{P}>0.05)$ when compared to control and did not show any significant differences between one another $(\mathrm{P}>0.05)$.

With regard to epinephrine associated to conditioned medium (cm, 10 and $50 \%$ ), it was found that the treatments under analysis, as well as $10 \%$ isolate or $50 \%$ conditioned medium use, induced a greater motility $(\mathrm{P}<0.05)$. The addition of $50 \%$ conditioned medium induced a higher motility, which may have been due to a higher concentration of self-inducers in the medium. This increase in motility has also been observed by other researchers when evaluating the use of catecholamines and conditioned medium in relation to Salmonella and other microorganisms (BEARSON \& BEARSON, 2008; SPERANDIO et al., 2001; SPERANDIO et al., 2002).

Such results may be due to the fact of catecholamines, as well as the presence of these self-inducers in the conditioned medium, induce cell multiplication (FREESTONE et al., 2007). Based on this, growth curves were performed with higher motility treatments; the results obtained showed that the presence of these molecules in BHI broth (Acumedia, USA) did not induce increased cell growth $(\mathrm{P}>0.05$, Figure 2$)$, that is, the higher motility found in this study did not result from a higher number of cells. 


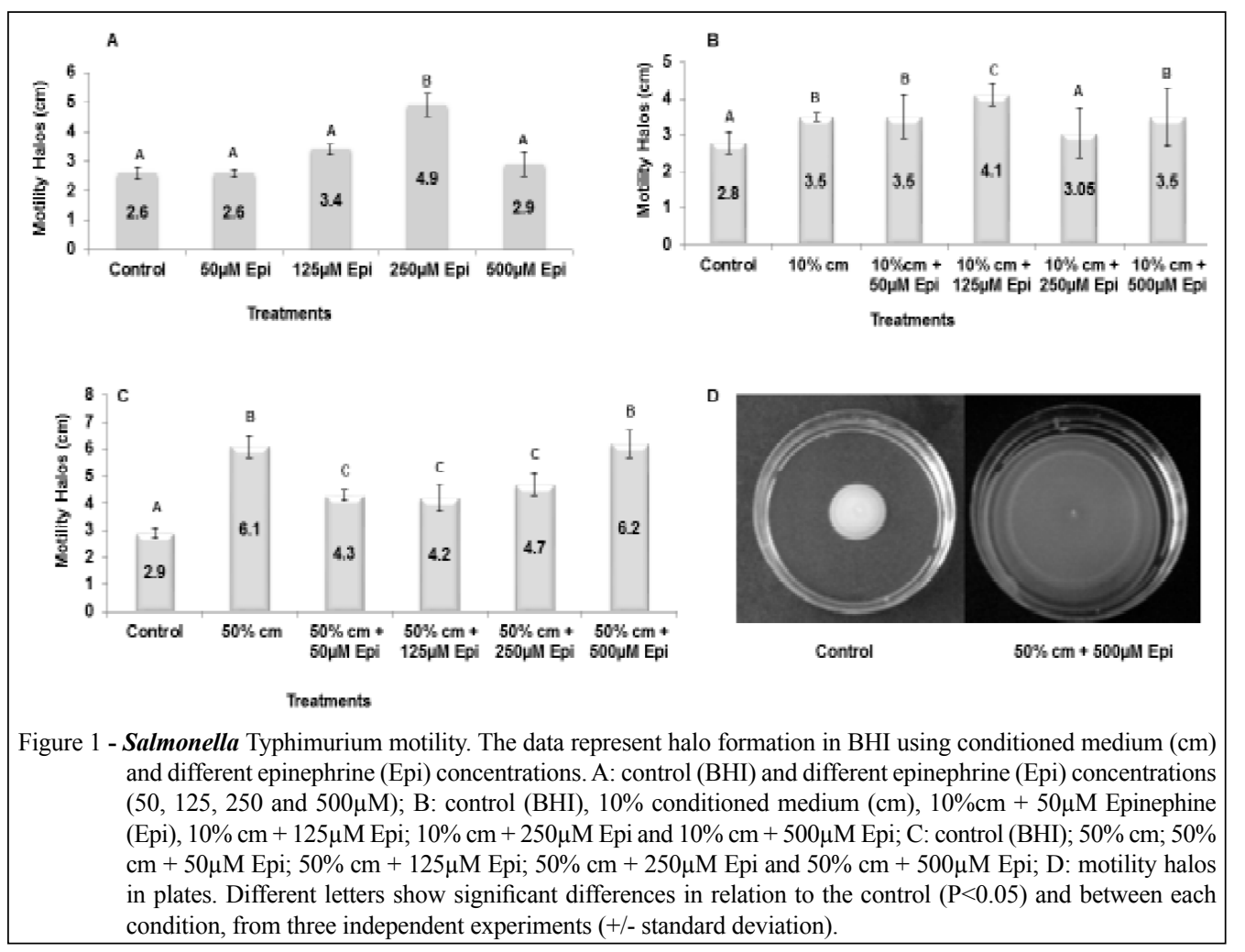

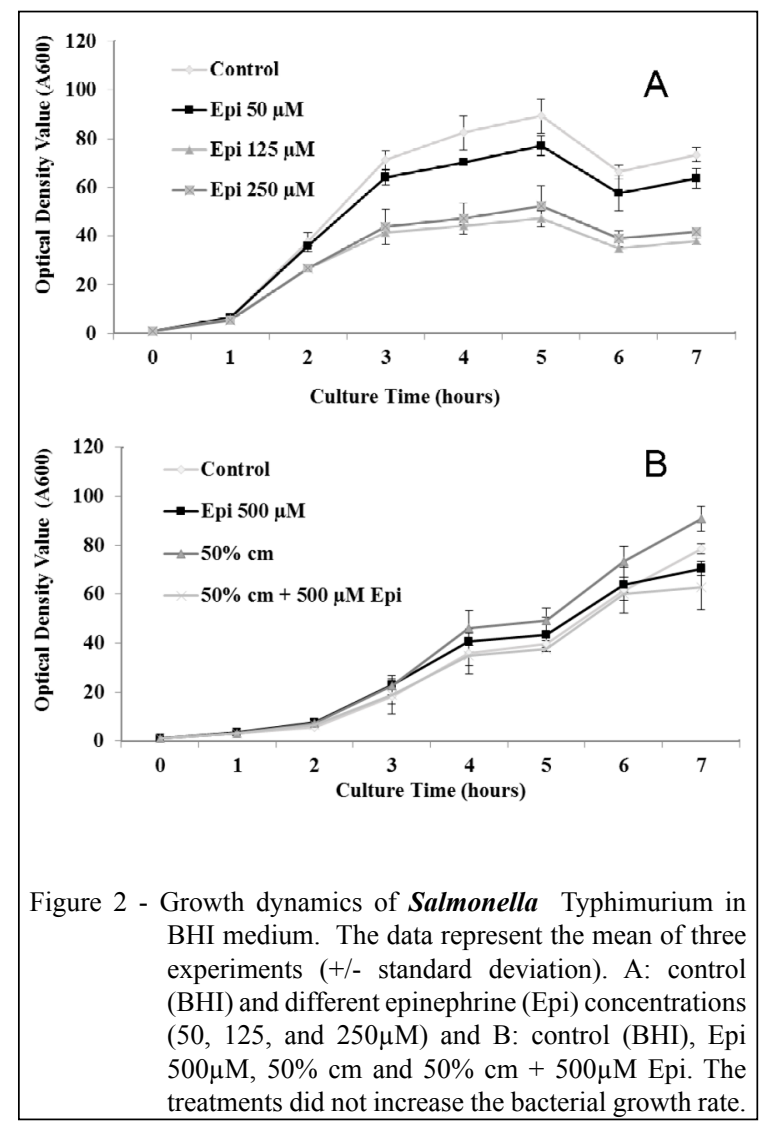

The other epinephrine concentrations were analyzed and a smaller cell proliferation was observed when the 125 and $250 \mu \mathrm{M}$ epinephrine media were used for the tested bacterium, as shown in figure 2B. The results obtained in this study differs from those found by FREESTONE et al. (2007), where the tested catecholamine concentrations $(0-500 \mu \mathrm{M})$ induced greater Salmonella enterica and Escherichia coli O157: H7 cell growth.

This may have occurred due to the culture medium used. Because BHI broth (Acumedia, Michigan, USA) is a complex and nutritious medium, there may have been an increased production of these autoinducers secreted in the medium, thus leading to a greater cell growth of the Salmonella strain tested, even in the absence of epinephrine and / or conditioned medium, i.e. in the control treatment (only BHI) reducing, as a result, the difference in growth as compared to the other treatments tested. Other factors that may have led to this result may be the catecholamine used, as well as inoculum size. FREESTONE et al. (2007) found norepinephrine to be the most potent catecholamine in inducing cell growth of the tested strains. These authors also mention that the ability of catecholamines to affect bacterial growth is initially more apparent at low cell density $\left(<10^{4} \mathrm{CFU} \mathrm{mL} \mathrm{mL}^{-1}\right)$, and greatest differences 
were observed at a $<10^{2} \mathrm{CFU} \mathrm{mL} \mathrm{m}^{-1}$ concentration, that is, upon simulating initial infection concentrations.

Due to the results obtained in growth curves, a second hypothesis was tested based on the fact that epinephrine and self-inducers could interfere with the expression of genes related to the flagellum assembly. This is a complex structure which requires more than 50 genes to be expressed (McQUISTON et al., 2008). Its expression occurs in a hierarchical order, encoding a regulator which coordinates intermediate gene transcription; the expression of these genes results in the assembly of the flagellum. The genes studied in this experiment were flhC, fliA, fliY, motA, motB and fliC, selected so that they would include this sequential order.

Quantitative PCR was performed in the treatment that associated epinephrine to the conditioned medium $(50 \% \mathrm{mc}+500 \mu \mathrm{M}$ adrenaline $)$, due to the results obtained in the motility assay. RTPCR analysis revealed a significant fliC increase when it was exposed to this treatment, suggesting that ST can use host as well as its own molecules to induce greater motility. A 21, 4.75, 3.4 and 2.2-fold increase in the expression of fliC, fliY, fihC and fliA genes, respectively (Figure 3) when compared to the control was observed.

This higher fliC expression was observed at 60 and 120 minutes, reaching a peak at 90 minutes. $\mathrm{A}$ higher motA and motB gene induction was not observed. Thus, a higher motility was due to an increased flagellum expression, as mentioned by other researchers (SPERANDIO et al., 2001; BEARSON \& BEARSON, 2008). Flagellin is the main flagellum protein, and its antigenic part is encoded by fliC or fljB genes. Salmonella can express up to two independent flagellin (McQUISTON et al., 2008), depending on

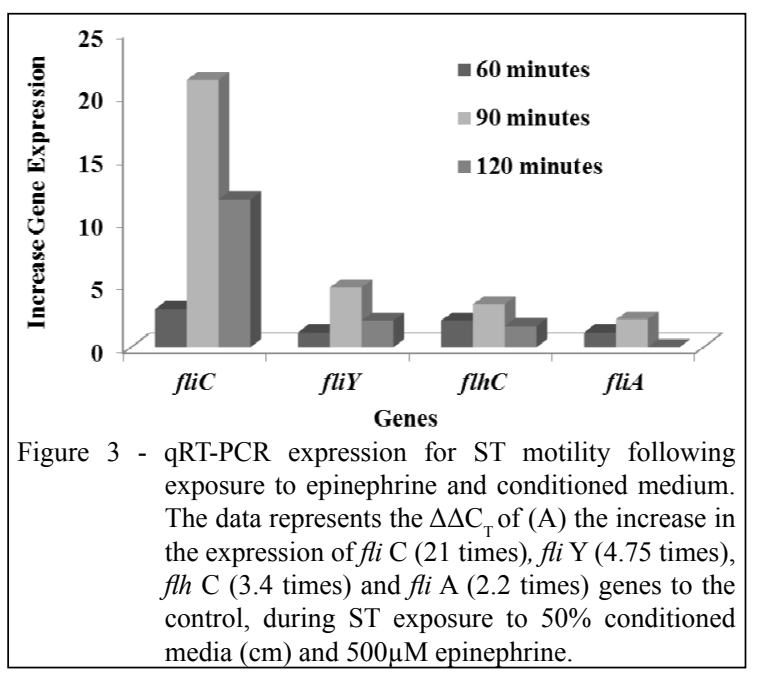

the serovar. The strain used in this experiment did not encode the second flagellin produced by the $\mathrm{fljB}$ gene, as previously observed.

\section{CONCLUSION}

The combination of $50 \%$ conditioned medium $+500 \mu \mathrm{M}$ epinephrine induced a higher motility, suggesting epinephrine is able to associate autoinducers produced by Salmonella Typhimurium and activate motility-related genes. Studies should be conducted to better understand the relation between these molecules and the bacterium studied.

\section{REFERENCES}

BEARSON, B.L.; BEARSON, S.M.D. The role of the QseC quorum-sensing sensor kinase in colonization and norepinephrineenhanced motility of Salmonella enterica serovar Typhimurium. Microbial Pathogenesis, v.44, n.4, p.271-278, 2008. Available from: <http://www.sciencedirect.com>. Accessed: Ago. 10, 2014. doi: 10.1016/j.micpath.2007.10.001

BOSILEVAC, J.M. et al. Prevalence and characterization of Salmonellae in commercial ground beef in the United States. Applied and Environmental Microbiology, v.75, n.7, p.18921900, 2009. Available from: <http://www.ncbi.nlm.nih.gov/pmc/ articles/PMC2663200/pdf/2530-08.pdf>. Accessed: Oct. 23, 2014. doi:10.1128/AEM.02530-08.

CENTERS FOR DISEASE CONTROL AND PREVENTION. CDC, Estimates of foodborne illness in the United States, 2011. Available from: <http://www.cdc.gov/foodborneburden>. Accessed: Ago 15, 2014.

FINK, R.C. et al. FNR is a global regulator of virulence and anaerobic metabolism in Salmonella enteric serovar Typhimurium (ATTCC 14028s). Journal of Bacteriology, v.189, p.22622273, 2007. Available from: <http://www.ncbi.nlm.nih.gov/ pmc/articles/PMC1899381/pdf/0726-06.pdf>. Accessed: Oct. 23, 2014. doi: 10.1128/JB.00726-06.

FREESTONE, P.P.E. et al. Specificity of catecholamine-induced growth in Escherichia coli O157:H7, Salmonella enterica e Yersinia enterocolitica. FEMS Microbiology Letters, v.269, p.221-228, 2007. Available from: <http://www.ncbi.nlm. nih.gov/pubmed/17229058>. Accessed: Oct. 10, 2014 . doi: 10.1111/j.1574-6968.2006.00619.x.

McQUISTON, J.R. et al. Do Salmonella carry spare tyres? Trends in Microbiology, v.16, n.4, p.142-148, 2008. Available from: $<$ http://www.ncbi.nlm.nih.gov/pubmed/18375124>. Accessed: Feb. 09, 2014. doi: 10.1016/j.tim.2008.01.009.

MOREIRA, C.G. et al. QseC mediates Salmonella enteric serovar Typhimurium virulence in vitro and in vivo. Infection and Immunity, v.78, n.3, p.914-926, 2010. Available from: <http://iai. asm.org/>. Accessed: Nov. 20, 2013. doi: 10.1128/IAI.01038-09.

MURMANN, L. et al. Prevalence, genetic characterization and antimicrobial resistance of Salmonella isolated from fresh pork sausages in Porto Alegre, Brazil. Food Control, v.20, p.191-195, 2009. Available from: <http://www.sciencedirect.com/science/ 
article/pii/S0956713508001011\#>. Accessed: Sep. 10, 2014. doi: 10.1016/j.foodcont.2008.04.007

O'DONNELL, P.M. et al. Enhancement of in vitro growth of pathogenic bacteria by norepinephrine: importance of inoculums density and role of transferring. Applied and Environmental Microbiology, v.72, p.5097-5099, 2006. Available from: <http:// www.ncbi.nlm.nih.gov/pmc/articles/PMC1489335/>. Accessed: Nov. 15, 2013. doi: 10.1128/AEM.00075-06.

SPERANDIO, V. et al. Bacteria-host communication:the language of hormones. Proceedings of the National Academy of Sciences of the USA, v.100, n.15, p.8951-8956, 2003. Available from: <http://www.pnas.org/cgi/doi/10.1073/pnas.1537100100>. Accessed: Sep. 13, 2014

SPERANDIO, V. et al. Quorum sensing is a global regulatory mechanism in enterohemorrhagic Escherichia coli O157:H7 Journal of Bacteriology, v.183, n.17, p.5187-5197, 2001. Available from: <http://jb.asm.org/>. Accessed: Dec. 16, 2012. doi: 10.1128/JB.183.17.5187-5197.2001.
SPERANDIO, V. et al. Quorum Sensing Escherichia coli regulators $\mathrm{B}$ and $\mathrm{C}(\mathrm{Q} s \mathrm{BC})$ : a novel two-component regulatory system involved in the regulation of flagella and motility by quorum sensing in E. coli. Molecular Microbiology, v.43, n.3, p.809-821, 2002.

STURBELLE, R.T. et al. The use of quorum sensing to improve vaccine immune response. Vaccine, v.32, p.90-95, 2013. Available from: <http://www.elsevier.com/locate/vaccine $>$. Accessed: Oct. 22, 2014. doi: 10.1016/j.vaccine.2013.10065.

TIMM, C.D. et al. Microbiology quality evaluation of pasty doce de leite. Revista do Instituto Adolfo Lutz, v.66, n.3, p. 275-277, 2007. Available from: <http://www2.ufpel.edu.br/veterinaria/inspleite/ documentos/2007/docemicro.pdf>. Accessed: Oct. 02, 2014.

WALTERS, M.; SPERANDIO, V. Autoinducer 3 and epinephrine signaling in the kinetics of locus of enterocyte effacement gene expression in enterohemorrhagic Escherichia coli. Infection and Immunity, v.74, n.10, p.5445-5455, 2006. Available from: $<$ http://iai.asm.org/>. Accessed: Oct. 28, 2014. doi: 10.1128/ IAI.00099-06. 